10. Нетрадиционные формы гимнастики : метод. рекомендации [Текст] / [сост.: Н.А. Дурдаева ]; Саран.кооп. ин-т РУК. - Саранск, 2009. - 28 с.

11. Приказ Минспорта РФ от 16.03.2017 №183 «О признании и включении во Всероссийский реестр видов спорта спортивных дисциплин, видов спорта и внесении изменений».- Всероссийский реестр видов спорта" Зар. в Минюсте России 13.04.2017 N 4635913 апреля 2017 г.

12. Физическое состояние студентов и возможные пути его совершенствования: учебно-методическое пособие для студентов вузов / В.И. Вишневский [и др.]; под ред. В.И. Вишневского. - М.: МАДИ, 2017. $-120 \mathrm{c}$.

13. Щербакова В.Л. Современные модели физкультурно-оздоровительной работы в системе физического воспитания вуза: учебно - методическое пособие - М.:Изд-во "Переспектива",2017. - 82с

14. www.cuder.sport.ua

\title{
Финашина T.B. \\ Организация системы военно-патриотического воспитания в условиях городского поселения
}

Президентская академия РАНХиГС (Россия, Москва)

doi:10.18411/lj-31-03-2018-52

idsp: 000001:lj-31-03-2018-52

\section{Аннотация}

В статье рассматриваются актуальность, значение, цели, задачи, направления, формы и методы патриотического воспитания российских школьников в условиях городского поселения. Обосновывается педагогическая программа патриотического воспитания.

Ключевые слова: воспитание, патриотизм, патриотическое воспитание школьников, патриотическое воспитание, воинский долг, система ценностей патриотического воспитания

Военно-Патриотическое воспитание представляет собой систематическую многомерную целенаправленную и слаженную деятельность государственных органов, общественных объединений и организаций по воспитанию у молодежи патриотического сознания, чувства верности своему Отечеству, готовности защищать его как основной Конституционный долг при защите национальных интересов Российской Федерации и обеспечении ее безопасности.

В настоящее время значительно возросла острота и востребованность военнопатриотического воспитания как конкретного направления патриотического воспитания.

Во-первых, в результате сложной военно-политической ситуации в мире и вокруг России, появления новых угроз ее национальной безопасности и вероятности возникновения вооруженных конфликтов с ее участием.

Во-вторых, в связи с высоким увеличением роли и важности повышения квалификации для военной службы молодежи до призывного возраста, повышается резкое сокращение ее продолжительности (до одного года).

В-третьих, из-за неудачных и безнадежных попыток найти долгое время альтернативу военно-патриотической ориентации в патриотическом воспитании как основной составляющей новообразованной системы этой деятельности.

Поэтому сегодня высоко повышается роль и значение образовательной организации, реализующей патриотическое и военно-Патриотическое воспитание, тем самым внося заметный вклад в воспитание у молодежи готовности к защите Отечества и военной службы. Этот вклад действительно реален. 
Национальные интересы России призывают государственные образовательные организации оказывать большее влияние на функционирование системы военнопатриотического воспитания и поддерживать молодежь в поиске лучшего выхода из проблем и тенденций развития общества и его военной организации.

Содержание военно-патриотического воспитания студентов, которую можно разделить на две основных взаимосвязанных задачи. Первый направлен на развитие гражданственности и патриотизма среди молодежи, умение взять на себя инициативу по укреплению нашего общества и государства. Вторая задача сочетается с целенаправленным воспитанием молодежи в готовности к успешному выполнению характерных функций по обеспечению военной безопасности Российской Федерации.

В системе военно-патриотического воспитания в мегаполисе, областном центре, городском поселении, селе будет выделяться множество составляющих и их иерархия. Городское поселение представляет собой сложный социокультурный феномен, имеющий обусловленный потенциал в социальном воспитании студентов, в их позитивной социализации, характеризующийся с экономической точки зрения, с точки зрения благосостояния и развития коммунального хозяйства, культурно-рекреационных и образовательных возможностей, особенностей демографических процессов и социальнопсихологического климата. Поэтому деятельность всех элементов системы военнопатриотического воспитания будет направлена на объединение потенциала и возрождение государственных институтов и общества в решении проблем воспитания гражданина, патриота, выпускника, готового к службе в Вооруженных Силах страны.

Как свидетельствуют результаты обобщения сформированного опыта военнопатриотического воспитания в условиях городского поселения, в практической деятельности учебных заведений существует ряд проблем: несогласованность программ и мероприятий, несогласованность в понимании целей и задач, в использовании форм и средств. Особенность организации такого образования в условиях городского поселения отмечается, что, во-первых, оно дислоцируется без поддержки воинских частей, вовторых, сосредоточено в некоторых школах, в-третьих, наименее используется потенциал учреждений культуры и религиозных организаций, военного комиссариата и управления внутренних дел, в-четвертых, процесс протекает дискретно. Учитывая эти обстоятельства, объединив усилия всех заинтересованных лиц и учреждений, можно строить систему военно-патриотического воспитания в городском поселении.

Эта система может быть подключена к центру патриотического воспитания в Департамент по делам молодежи администрации муниципалитета. Центру патриотического воспитания будет способствовать зачинщик, интегратор, координатор всех мероприятий на территории города, имеющих военно-патриотическую направленность (военный комиссариат, отдел внутренних дел, школы, профессиональные училища, все учреждения дополнительного образования, общественные организации, учебно-воспитательный Отдел епархии, детские ветеранские организации, Совет ветеранов). Деятельность всех элементов этой системы направлена на объединение их возможностей в решении проблем воспитания гражданина, патриота, выпускника, находящегося на службе Вооруженных сил страны, на активизацию работы государственных структур и общественности в этом направлении.

Придание военно-патриотическому воспитанию последовательности будет способствовать формированию образа такого воспитания, которое нашло свое выражение в модели, содержащей целевые, содержательные, процедурные и продуктивные блоки.

Целевое подразделение будет направлено на: ознакомление студентов с прошлым, настоящим страны и вооруженных сил, ее лучших представителей; на помощь ей в 
понимании важности межпоколенческих отношений, сути обычаев, путей их хранения и совершенствования; на вовлечение в социально-трансформативную деятельность; на подготовку морально и физически служить в Вооруженных Силах страны.

Контент-блок соединит образовательные и познавательные, поисковоисследовательские, спортивно-рекреационные, социальные и полезные направления и будет базироваться на принципах целостности, сложности, преемственности, событийности, вариативности, эмоциональности, ориентации на возраст и индивидуальные возможности студентов.

Наиболее перспективным с точки зрения реализации существенного блока военнопатриотического воспитания в городском поселении является использование сложных комбинированных интегрированных форм. Такие формы могут быть выдвинуты поисковая работа; военно-спортивные лагеря; образовательные поездки; военнопатриотические клубы (объединения) различной направленности; военно-спортивные праздники; фестивали, песни; фестивали и т. д.

Эти формы содержат целый ряд многогранных мероприятий, которые проводятся систематически, с должной цикличностью, в соответствии с научно обоснованными организационными условиями, способствующими реализации основных задач военнопатриотического воспитания. Кроме того, они синтезируют основные элементы как совместного, так и специального содержания военно-патриотического воспитания в узко взаимосвязанной и взаимодополняющей форме. Это позволяет в значительной мере преодолеть разрыв между теоретическими и практическими компонентами применения военно-патриотического воспитания, его общей направленностью и конкретными задачами.

Процедурный блок будет состоять из диагностических, организационных, праксиологических и аналитических элементов, которые тесно взаимосвязаны.

Оценочно-эффективный блок предусматривает определение эффективности предложенной модели по нескольким критериям: когнитивный (уровень знаний о прошлом и настоящем страны, армии), ценностно-ориентированный (характер ценностей, их направление и иерархия), праксиологический (уровень формирования жизненных навыков), мотивационный (наличие мотивов служения Отечеству), поведенческий (поведение, действия молодежи в актуальных ситуациях, вызывающих самостоятельное и ответственное принятие решений).

Таким образом, содержание военно-патриотического воспитания студентов может рассматриваться как основа развития важнейших внутренних, нравственных, социальных и патриотических ценностей, официально приобретенных национальным статусом и поддержанных гражданами общества. Под влиянием системы идей, эти ценности преломляются и трансформируются в движение социального развития. Они издаются как отправная точка для интеграции и единства России, Российского государства, как важнейшие ориентиры для воспитания гражданина-патриота-защитника Отечества.

$$
* * *
$$

1. Бурьян К.В. Система военно-патриотического воспитания старшеклассников средствами клубной работы: дис. ... канд. пед. наук. - Уфа., 2005. - 176 с.

2. Войкин А.Ю. Военно-патриотическое воспитание учащейся молодежи в малом городе: автореф. дисс. ... канд. пед. наук. - Кострома, 2007. - 23 с.

3. Микрюков В.Ю. Военно-патриотическое воспитание в школе: 1-11 классы. - М.: ВАКО, 2009. - 192 с.

4. Микрюков В.Ю. Теория и практика военно-патриотического воспитания в современной России: автореф. дисс. ... докт. пед. наук. - М., 2009. - 25 с.

5. Российский патриотизм: истоки, содержание, воспитание в современных условиях: учеб.пособие / под общ. ред. А.К. Быкова и В.И. Лутовинова. - М.: Планета, 2010. - 336 с. 